Journal of Aafiyah Health Research (JAHR)

P-ISSN: 2722-4929 \& E-ISSN: 2722-4945

Published by Postgraduate Program in Public health, Muslim University of Indonesia

Original Research

Open Access

\title{
Hubungan Antara Pengetahuan, Sikap dan Kualitas Kerja Dengan Kinerja Perawat Dalam Penerapan Sistem Keselamatan Pasien Di RSUD Sinjai Tahun 2020
}

\author{
*Muhammad Iqbal ${ }^{1}$, Suharni A Fachrin², Lalu Muhammad Saleh ${ }^{3}$ \\ ${ }^{1}$ Program Pascasarjana Kesehatan Masyarakat, Universitas Muslim Indonesia \\ ${ }^{2}$ Ilmu Kesehatan Masyarakat, Fakultas Kesehatan Masyarakat, Universitas Muslim Indonesia \\ ${ }^{3}$ Ilmu Kesehatan Masyarakat, Fakultas Kesehatan Masyarakat, Universitas Hasanuddin
}

*Email:mi8081619@gmail.com

\begin{abstract}
ABSTRAK
Latar belakang: Perawat sebagai tenaga kesehatan yang bertugas di garis depan pelayanan memerlukan pengetahuan, sikap yang mendukung penerapan sistem keselamatan pasien dan kualitas kerja yang baik serta kinerja perawat sebagai proses pelayanan. Keselamatan pasien di rumah sakit adalah sistem rumah sakit untuk membuat asuhan pelayanan pasien yang lebih aman. Aman dari kemungkinan terjadinya risiko Insiden Keselamatan Pasien (IKP). Penelitian ini bertujuan untuk menganalisis hubungan pengetahuan, sikap dan kualitas kerja dengan kinerja perawat dalam penerapan sistem keselamtan pasien di RSUD Sinjai. Metode: Penelitian ini menggunakan metode kuantitatif dengan rancangan penelitian cross-sectional dan besar sampel penelitian adalah 114 perawat dan 11 kepala ruangan. Data dikumpulkan menggunakan kuesioner yang mengacu pada panduan nasional sistem keselamatan pasien, pedoman pelaporan IKP dan materi Joint Commission International (JCI) yang meliputi International Patient Safety Goals (IPSG) 1-6. Analisis data dilakukan secara univariat, bivariate dengan uji chi-square dan analisis multivariate dengan regresi linear berganda. Hasil: Penelitian menunjukkan bahwa ada hubungan pengetahuan, sikap dan kualitas kerja dengan kinerja perawat dalam penerapan sistem keselamatan pasien $(\rho$ value $=0,000)$, dan ada hubungan secara simultan pengetahuan, sikap dan kualitas kehidupan kerja dengan kinerja perawat dalam penerapan sistem keselamatan pasien di rumah sakit umum daerah sinjai sebesar 52\% dengan $\mathrm{F}$ hitung 58,498 bermakna (karena > F tabel 3,08). Kesimpulan: Perlu adanya sosialisasi dan pelatihan terkait sistem keselamatan pasien untuk meningkatkan kinerja perawat dalam menunjang mutu pelayanan di rumah sakit umum daerah sinjai.
\end{abstract}

Kata Kunci: Pengetahuan, Sikap, Kualitas Kerja, Kinerja, Sistem Keselamatan Pasien 


\begin{abstract}
Background: Nurses as health workers who serve at the forefront of services need knowledge, attitudes that support the application of a patient safety system and good quality work and nurse performance as a service process. Patient safety in a hospital is a hospital system to make patient care safer. Safe from the possibility of the risk of a Patient Safety Incident . This study aims to analyze the relationship between knowledge, attitudes and quality of work with the performance of nurses in the application of the patient safety system at RSUD Sinjai. Methods: This study used a quantitative method with a cross-sectional study design and the sample size was 114 nurses and 11 room heads. Data were collected using a questionnaire that refers to the national patient safety system guidelines, the IKP reporting guidelines and the Joint Commission International (JCI) material which includes the International Patient Safety Goals (IPSG) 1 - 6. Data analysis was carried out univariate, bivariate with the chi-square test and multivariate analysis with multiple linear regression. Results: The study shows that there is a relationship between knowledge, attitudes and work quality with the performance of nurses in implementing the patient safety system ( $\rho$ value $=0.000$ ), and there is a simultaneous relationship between knowledge, attitudes and quality of work life with the performance of nurses in implementing the patient safety system at home. General illness in the sinjai area was $52 \%$ with F count 58.498 significant (because F table > 3.08). Conclusion: There is a need for socialization and training related to patient safety systems to improve the performance of nurses in supporting the quality of service at the Sinjai regional public hospital.
\end{abstract}

Keywords: Knowledge, Attitude, Quality of Work, Performance, Patient Safety System

\section{LATAR BELAKANG}

Keselamatan pasien merupakan prioritas utama yang harus dilakukan oleh Rumah Sakit. Hal ini sangat erat kaitannya baik dengan citra rumah sakit maupun keamanan pasien. Tujuan dari penerapan keselamatan pasien di rumah sakit adalah untuk melindungi pasien dari kejadian yang tidak diharapkan. Resiko kejadian ini berasal dari proses pelayanan yang dilakukan oleh tenaga kesehatan melalui program - program yang telah ditetapkan oleh Rumah Sakit (1).

Kasus tentang keselamatan pasien telah menjadi perhatian beberapa negara di dunia dikarenakan masih tetap ada kejadian yang tidak diharapkan (KTD). Centers for Disease
Control and Prevention (dalam Saleh et.al, 2010) memperkirakan lebih dari 380.000 cedera akibat dari benda tajam yang terjadi pada petugas pelayanan kesehatan di Rumah Sakit Amerika. Diperkirakan dari semua kasus cedera petugas pelayanan kesehatan, 600.000 sampai 800.000 tertusuk oleh jarum suntik atau benda tajam lainnya yang terkontaminasi oleh pathogen darah seperti HIV, Virus Hepatitis B dan Virus Hepatitis C. Kejadian tidak diharapkan di rumah sakit dari berbagai negara (Amerika, Inggris, Denmark, dan Australia) yang memiliki rentang KTD sebesar 3,2-16,6\% (2).

Di Indonesia, pelaporan insiden keselamatan pasien berdasarkan provinsi pada tahun 2010 ditemukan 
Jawa Barat 33,33\%, Banten dan Jawa Tengah 20\%, DKI 16,67\%, Makassar 10,4\%, Bali 6,6\% dan Jatim 3,33\% (3). Data tersebut menjadi pemicu diberbagai negara untuk melakukan penelitian dan pengembangan Sistem Keselamatan Pasien (Depkes RI, 2015) dan Kasus tersebut yang mendorong pemerintah Indonesia untuk lebih memberikan perhatian khususnya terhadap masalah keselamatan pasien di rumah sakit. Hal ini dibuktikan dengan diterbitkannya Peraturan Menteri Kesehatan (PMK) Nomor 1691 Tahun 2011 tentang keselamatan pasien di rumah sakit (4).

Tentunya kejadian insiden keselamatan pasien di suatu rumah sakit akan memberikan dampak yang merugikan bagi pihak rumah sakit, staf, dan pasien sebagai penerima pelayanan. Keselamatan pasien (Patient Safety) rumah sakit adalah suatu, sistem dimana rumah sakit membuat asuhan pasien lebih aman (5).

Kinerja merupakan landasan bagi pencapaian tujuan suatu organisasi yaitu Penerapan sistem keselamatan pasien. Keberhasilan organisasi dalam meningkatkan kinerjanya sangat bergantung pada kualitas sumber daya manusia yang bersangkutan dalam bekerja selama berada pada organisasi tersebut. Banyak faktor yang dapat mempengaruhi Kinerja Perawat, antara lain motivasi, kepemimpinan, lingkungan kerja, disiplin kerja, budaya kerja, pengetahuan, sikap, perilaku, komunikasi, komitmen, jabatan, Kualitas Kerja, pelatihan, beban kerja, kompensasi, kepuasan kerja, dan masih banyak yang lain. Dalam penelitian ini, faktor - faktor yang mempengaruhi kinerja perawat difokuskan pada pengetahuan, sikap dan Kualitas Kerja perawat (5).

Menurut Gunibala (2015), pengetahuan merupakan faktor penting seseorang dalam mengambil keputusan, namun tidak selamanya pengetahuan seseorang bisa menghindarkan dirinya dari kejadian yang tidak diinginkannya (6). Pengetahuan dan sikap sangat diperlukan untuk menghasilkan perilaku dalam hal ini berupa kualitas pelayanan yang baik, dalam pelaksanaan pelayanan, perawat merupakan bagian tenaga kesehatan yang paling banyak berhubungan langsung dengan pasien. Menurut Notoatmodjo (2010) terdapat enam factor yang dapat mempengaruhi Pengetahuan, yaitu: Umur, pendidikan, paparan media massa, social ekonomi, hubungan sosial dan pengalaman. Sedangkan sikap merupakan kumpulan respon yang masih tertutup terhadap stimulus atau objek, sehingga sikap itu melibatkan pemikiran, perasaan, perhatian dan gejala kejiwaan yang lain (7). Faktor yang mempengaruhi skap menurut Azwar (2007) adalah pengalaman pribadi, pengaruh orang lain yang diangap penting, pengaruh budaya, media Massa, lembaga pendidikan dan factor emosional (8).

Disamping itu, kualitas Kerja merupakan masalah utama yang patut mendapat perhatian organisasi. Hal ini merujuk pada pemikiran bahwa Kualitas Kerja dipandang mampu untuk meningkatkan peran serta perawat terhadap organisasi (rumah sakit). Menurut Wayne dalam 
Mahardikawanto (2013) pada teori Kualitas Kerja dikatakan bahwa para manajer memberikan kesempatan bagi para karyawan untuk mendesain pekerjaan mereka tentang apa yang dibutuhkan dalam menghasilkan produk atau jasa agar mereka dapat bekerja secara efektif (9). Penelitian Arifin (2012) menunjukkan bahwa terdapat pengaruh antara Kualitas Kerja terhadap kinerja karyawan. Semakin baik Kualitas Kerja karyawan akan mampu meningkatkan kinerja karyawan (10).

Penerapan Sistem Keselamatan Pasien di Rumah Sakit di Indonesia belum inherent/melekat dalam setiap kegiatan pelayanan kesehatan kepada pasien sehari-hari, beberapa aktivitas berkaitan dengan program keselamatan pasien akan lebih meningkat pada saat rumah sakit menjelang penilaian Akreditasi Nasional. Sangat kompleks faktor-faktor yang berpengaruh dalam penerapan Sistem Keselamatan Pasien Rumah Sakit Umum Daerah Sinjai. Penerapan sistem keselamatan pasien di Indonesia mengacu pada materi Panduan Nasional Sistem Keselamatan Pasien, Pedoman Pelaporan Insiden Keselamatan Pasien (IKP) dan Joint Commissson International (JCI) yang meliputi IPSG 1/6 (11).

Kemudian data yang didapatkan peneliti bahwa masih ada IKP di RSUD Sinjai yaitu dapat dilihat dari data kecelakan pada tahun 2018 di ruang rawat inap di RSUD Sinjai terdapat kecelakaan pasien yaitu kena pecah anampulan (17 kejadian), tertusuk jarum bekas pakai (3 kejadian), jatuh dari kursi (3 kejadian), terpeleset karena lantai licin (2 kejadian), kena pecahan tehel (1 kejadian), terpleset dikamar mandi (1 kejadian), pasien jatuh dari tempat tidur (1 kejadian), tertusuk pinset (1 kejadian) (12).

Berdasarkan hal tersebut peneliti tertarik untuk melakukan penelitian yang Menganalisis Hubungan Pengetahuan, Sikap dan Kualitas Kerja dengan Kinerja Perawat dalam Penerapan Keselamatan Pasien di RSUD Sinjai.

\section{METODE}

Penelitian ini merupakan penelitian kuantitatif dengan pendekatan Cross sectional study. Penelitian ini dilakukan di Rumah Sakit Umum Daerah Sinjai pada bulan Januari sampai bulan Maret 2020.

\section{Populasi dan sampel}

Populasi dalam penelitian ini adalah seluruh tenaga keperawatan di Rumah Sakit Umum Daerah Sinjai yang telah bekerja selama 6 bulan karena perawat yang bekerja selama 6 bulan sudah dianggap dapat beradaptasi dengan lingkungan kerja dan perawat yang telah mendapatkan pelatihan tentang keselamatan pasien. Adapun jumlah perawat di Rumah Sakit Umum Daerah Sinjai sebanyak 292 orang. Khusus untuk penilaian kinerja perawat responden yang diteliti adalah atasan langsung perawat/kepala ruangan di unit kerja pelayanan.

Teknik pengambilan sampel dalam penelitian ini yaitu dengan menggunakan metode non probability sampling yaitu Purposive Sampling. 
Pada penelitian ini kriteria inklusi responden adalah perawat yang telah bertugas di unit kerja pelayanan minimal 6 (enam) bulan dan pernah mendapat pendidikan-pelatihan dengan topik sistem keselamatan pasien minimal satu kali serta pendidikan minimal D3. Kriteria inklusi untuk penilaian kinerja adalah kepala ruangan yang telah menjabat sebagai kepala ruangan minimal enam bulan. Total sampel dalam penelitian ini adalah sebanyak 125 orang ynag terdiri dari 114 orang perawat dan 11 orang kepala ruangan yang berstatus PNS maupun Non PNS di Rumah Sakit Umum Daerah Sinjai.

\section{Variabel}

\section{Variabel Independent (bebas)}

Pengetahuan adalah hal-hal yang diketahui perawat tentang materi sistem keselamatan pasien dan asuhan keperawatan. Cara mengukurnya dengan menjawab atau mengisi kuesioner, dengan penilaian angka adalah skor 2 jika Jawaban Benar (B), dan skor 1 jika Jawaban Salah (S).

Sikap adalah penilaian menurut persepsi perawat tentang materi sistem keselamatan pasien dan asuhan keperawatan. Kualitas Kerja adalah penilaian menurut persepsi perawat yang dirasakan dan dialami terhadap suasana kehidupan di lingkungan unit kerja rumah sakit. Pemberian skor untuk dua variable tersebut adalah skor 4 jika sangat setuju (SS), 3 jika setuju
(S), 2 jika tidak setuju (TS) dan 1 jika sangat tidak setuju (STS).

\section{Variabel Dependent (terikat)}

Kinerja Perawat adalah penilaian hasil kerja perawat oleh atasan langsung/kepala ruangan, berkaitan dengan materi Sistem Keselamatan Pasien dan asuhan keperawatan. Pemberian skor untuk variable ini adalah skor 4 jika sangat setuju (SS), 3 jika setuju (S), 2 jika tidak setuju (TS) dan 1 jika sangat tidak setuju (STS).

Adapun, penentuan kriteria objective seluruh variable independent dan adalah "Baik" jika persentase jawaban responden $\geq 62,5 \%$. "Kurang" Kurang baik" Jika persentase jawaban responden $<62,5 \%$ (13).

\section{Sumber dan Pengumpulan data}

Metode pengumpulan data yang digunakan yakni wawancara (Interview) yaitu pengumpulan data melalui wawancara secara langsung kepada perawat. Dan kuesioner yaitu melakukan pengumpulan data melalui pembagian daftar pertanyaan kepada responden.

\section{Analisis Data}

Analisis data dilakukan melalui tahap editing, coding, tabulasi dan uji statistic. Uji statistic yang digunakan adalah univariat, bivariate dan multivariat dengan menggunakan komputerisasi yakni program Statistical Product and service Solution (SPSS). 


\section{HASIL}

\section{Karakterisktik Responden}

Table 1. Karakteristik Responden Di Rumah Sakit Umum Daerah Sinjai Tahun 2020

\begin{tabular}{lll}
\hline Variabel & $\mathbf{n}=\mathbf{1 1 4}$ & $\mathbf{\%}$ \\
\hline Umur & & \\
$17-25$ Tahun & 4 & 3,5 \\
$26-35$ Tahun & 13 & 11,4 \\
$36-45$ Tahun & 97 & 85,1 \\
& & \\
Jenis Kelamin & 33 & 28,9 \\
Laki - laki & 81 & 71,1 \\
Perempuan & & \\
Pendidikan & 48 & 42,1 \\
D3 & 9 & 7,9 \\
S1 & 57 & 50 \\
S1 + Ners & & \\
Sumber: Data Primer & &
\end{tabular}

Berdasarkan tablel 1 Karakteristik responden diketahui perawat paling banyak berumur 36 - 45 tahun yaitu 97 orang $(85,1 \%)$ dan paling sedikit berumur 17 - 25 Tahun yaitu 4 orang $(3,5 \%)$. Jenis kelamin perempuan paling banyak 81 orang $(71,1 \%)$ kemudian laki-laki 33 orang (28,9\%). Tingkat pendidikan paling banyak adalah S1+Ners sebanyak 57 orang $(47,6)$ dan paling sedikit S1 yaitu 9 orang $(7,9 \%)$.

Table 2. Distribusi Pengethuan, Sikap, Kualitas Kerja dan Kinerja Perwat Di Rumah Sakit Umum Daerah Sinjai Tahun 2020

\begin{tabular}{|c|c|c|c|}
\hline \multicolumn{2}{|c|}{ Variabel Penelitian } & \multirow{2}{*}{$\begin{array}{c}\mathbf{n = 1 1 4} \\
70\end{array}$} & \multirow{2}{*}{$\begin{array}{c}\% \\
61,4\end{array}$} \\
\hline Pengetahuan & Baik & & \\
\hline & Kurang & 44 & 38,6 \\
\hline \multirow[t]{2}{*}{ Sikap } & Baik & 67 & 58,8 \\
\hline & Kurang & 47 & 41,2 \\
\hline \multirow[t]{2}{*}{ Kualitas Kerja } & Baik & 74 & 64,9 \\
\hline & Kurang & 40 & 35,1 \\
\hline \multirow[t]{2}{*}{ Kinerja Perawat } & Baik & 73 & 64,0 \\
\hline & Kurang & 41 & 36,0 \\
\hline
\end{tabular}

Berdasarkan tabel 2 menunjukan bahwa pengetahuan perawat baik sebanyak 70 orang $(61,4 \%)$ dan pengetahuan perawat kurang sebanyak 44 orang $(38,6)$. Perawat yang memiliki sikap baik sebanyak 67 orang $(58,8 \%)$ dan 
sikap kurang sebanyak 47 orang (41,2\%). Perawat dengan kualitas kerja baik sebanyak 74 orang $(64,9)$ dan kualitas kerja kurang sebanyak 40 orang $(35,1 \%)$, kemudian kinerja perawat baik yaitu sebanyak 73 orang (64\%) dan kinerja perawat kurang sebanyak 41 orang $(36 \%)$.

Table 3. Pengetahuan, Sikap dan Kualitas Kerja Terhadap Kinerja Perawat Di Rumah Sakit Umum Daerah Sinjai Tahun 2020

\begin{tabular}{lllcccc}
\hline \multirow{2}{*}{ Variabel Penelitian } & \multicolumn{3}{c}{ Kinerja Perawat } & \multicolumn{2}{c}{$\boldsymbol{\rho}$} \\
& & Baik & \multicolumn{2}{c}{ Kurang } & value \\
& Baik & 57 & 81,4 & 13 & 18,6 & 0,000 \\
& Kurang & 16 & 36,4 & 28 & 63,6 & \\
\hline Sikap & Baik & 58 & 86,6 & 9 & 13,4 & 0,000 \\
& Kurang & 15 & 31,9 & 32 & 68,1 & \\
\hline Kualitas Kerja & Baik & 63 & 85,1 & 11 & 14,9 & 0,000 \\
& Kurang & 10 & 25,0 & 30 & 75,0 & \\
\hline
\end{tabular}

Sumber: Data Primer

Berdasarkan tabel 3 menunjukan perawat yang memiliki pengetahuan baik yaitu sebanyak 70 orang (100\%), diantaranya responden dengan pengetahuan baik dan memiliki kinerja yang baik sebanyak 57 orang $(81,4 \%)$ dan sebanyak 13 orang $(18,6 \%)$ dengan pengetahuan baik namun memiliki kinerja kurang, sedangkan perawat dengan pengetahuan kurang yaitu sebanyak 44 orang (100\%) diantaranya perawat dengan pengatahuan kurang memiliki kinerja yang baik sebanyak 16 orang $(36,4 \%)$, sebanyak 28 orang $(63,6 \%)$ dengan kinerja yang kurang. Hasil uji statistic Chi Square di peroleh nilai $\rho=0.000$ maka dapat disimpulkan bahwa ada hubungan antara pengetahuan dengan kinerja perawat dalam penerapan sistem keselamatan pasien di Rumah Sakit Umum Daerah Sinjai.

Perawat dengan sikap baik yaitu 67 orang $(100 \%)$, yang memiliki kinerja yang baik sebanyak 58 orang $(86,6 \%)$ dan 9 orang $(13,4 \%)$ memiliki kinerja yang kurang, sedangkan perawat dengan sikap kurang yaitu 47 orang (100\%), yang memiliki kinerja baik sebanyak 15 orang $(31,9 \%)$ dan 32 orang $(68,1 \%)$ memiliki kinerja yang kurang. Hasil uji statistic Chi Square di peroleh nilai $\rho=0.000$ disimpulkan bahwa ada hubungan antara sikap dengan kinerja perawat dalam penerapan sistem keselamatan pasien di Rumah Sakit Umum Daerah Sinjai.

Perawat dengan kualitas kerja baik 74 orang (100\%), perawat dengan kualitas kerja baik dan memiliki kinerja yang baik sebanyak 63 orang $(85,1 \%)$, 11 orang $(14,9 \%)$ dengan kinerja yang kurang, sedangkan perawat dengan kualitas kerja kurang yaitu 40 orang (100\%) yang memiliki kualitas kerja kurang namun memiliki kinerja yang baik sebanyak 10 orang (25\%) dan 30 orang $(75 \%)$ memiliki kinerja yang 
kurang. Hasil uji statistic Chi Square di peroleh nilai $\rho=0.000$ maka dapat disimpulkan bahwa ada hubungan antara kualitas kerja dengan kinerja perawat dalam penerapan sistem keselamatan pasien di Rumah Sakit Umum Daerah Sinjai.

Table 4. Hasil Uji Multivariat Variabel Penelitian

\begin{tabular}{cccc}
\hline F tabel & Fhitung & Sig & R Square \\
\hline $\mathbf{3 , 0 8}$ & 58,498 & 0,000 & 0,52
\end{tabular}

\section{Sumber: Data Primer}

Tabel 4 adalah hasil analisis regresi linear berganda untuk melihat ada tidaknya hubungan variabel-variabel bebas (Pengetahuan, Sikap dan Kualitas Kerja) dengan variabel terikat (Kinerja Perawat) secara simultan. Uji Anova dengan menggunakan SPSS, didapatkan $F_{\text {hitung }}$ adalah 58,498 dan $\mathrm{F}_{\text {tabel }}$ dengan df1 = k-1 = 3-1 = 2 dan $\mathrm{df} 2=\mathrm{n}-\mathrm{k}-2=114-3-2=109$, maka $F_{\text {tabel }}(\mathrm{df1})(\mathrm{df} 2)=3,08$ dapat disimpulkan bahwa $\mathrm{F}_{\text {hitung }}>\mathrm{F}_{\text {tabel }}$ yang menunjukkan bahwa variabel pengetahuan, sikap dan kualitas kerja secara simultan berhubungan dengan kinerja perawat dalam penerapan sistem keselamatan pasien di RSUD Sinjai dengan persentase hubungan sebesar $52 \%$, untuk pengetahuan $10 \%$, sikap $20,4 \%$ dan kualitas kerja $21,6 \%$.

\section{PEMBAHASAN}

\section{Pengetahuan dan Kinerja Perawat}

Pengetahuan merupakan faktor dominan dalam mencapai tingkatan ketrampilan tertentu. Dengan pengetahuan yang baik maka individu akan lebih mudah mengembangkan ketrampilan dengan latihan-latihan yang cukup (14).
Hasil penelitian menunjukkan bahwa perawat yang memiliki pengatahuan kategori baik dengan kinerja baik sebesar 81,4\% dan kurang 18,6\% artinya bahwa dengan pengetahuan yang baik tentang materi sistem keselamatan pasien akan meningkatkan kinerja perawat dalam penerapan sistem keselamatan pasien.

Menurut Notoatmodjo (2007), Pengetahuan merupakan modal utama didapatkannya keterampilan dan sikap yang baik, dengan pengetahuan yang baik, individu akan termotivasi meningkatkan perilaku kesehatan, dengan demikian dapat disimpulkan pengetahuan perawat tentang sistem keselamatan pasien sebagian besar adalah baik, sehingga perawat di harapkan mampu menerapkan sistem keselamatan pasien dengan baik, kemudian perawat yang memiliki pengetahuan kategori kurang dengan kinerja kurang 63,6\% dan baik 36,4\% dari hasil ini disimpulkan bahwa dengan pengetahuan kurang tentang materi keselamatan pasien akan mempengaruhi kinerjanya dalam penerapan sistem keselamatan pasien, terkait dengan konsep manajemen SDM bahwa pengetahuan dinyatakan sebagai 
syarat penting terbentuknya perilaku (14).

Hal ini sejalan dengan Mangkuprawira (2008) yang menyatakan bahwa pengetahuan merupakan unsur pokok bagi setiap perawat untuk merubah perilakunya dalam mengerjakan sesuatu, perawat yang hanya menggunakan pengetahuan yang sekedarnya akan semakin tertinggal kinerjanya dibanding perawat yang selalu menambah pengetahuannya yang baru (15). Hal ini semakin memperjelas bahwa pengetahuan tidak hanya dapat dipandang sebagai investasi yang bermanfaat pada waktu tertentu saja akan tetapi bagaimana pengetahuan mempengaruhi kinerja perawat pada periode pekerjaan, pengetahuan perawat merupakan suatu hal yang penting diperhatikan dalam mengelola SDM. Hasil penelitian ini mendukung penelitian Sri Yulia (2010) bahwa dalam rangka memfasilitasi transfer pengetahuan program pelatihan keselamatan pasien dan pengembangkan standar kinerja perlu dilakukan secara berkelanjutan (16).

Berdasarkan uji statistik diperoleh bahwa ada hubungan pengetahuan dengan kinerja perawat dalam penerapan sistem keselamatan pasien di Rumah Sakit Umum Daerah Sinjai dengan nilai $p=0,000$. Hasil ini menunjukkan kesamaan dengan penelitian terkait Hubungan Pengetahuan dan Sikap Perawat terhadap penerapan Standar Operasional Prosedur (SOP) Teknik menyuntik dalam Upaya pencegahan infeksi di RSUD Arifin Achmad Pekanbaru, yang mendapatkan hasil ada hubungan yang bermakna antara variabel pengetahuan terhadap penerapan SOP teknik menyuntik (dengan $\mathrm{p}=0,025)$ dalam upaya pencegahan infeksi di RSUD Arifin Achmad Pekanbaru. (17).

Asumsi peneliti terkait hal ini adalah upaya meningkatkan pengetahuan tetap merupakan suatu hal yang penting khususnya dalam konteks keselamatan pasien. Hal ini didukung oleh pendapat Notoadmodjo (2010) yang menyatakan bahwa pengetahuan yang menunjang keterampilan perlu diberikan agar karyawan dalam hal ini perawat dapat melakukan tugasnya berdasarkan teoriteori yang dapat dipertanggungjawabkan (18). Hal ini berarti bahwa keterbatasan pengetahuan merupakan hal kunci sangat perlu dipertimbangkan demi keamanan asuhan keperawatan yang diberikan oleh tenaga kesehatan termasuk perawat. Untuk mencapai peningkatan pengetahuan pelatihan dan peran pengorganisasian hal sesuai penelitian yang dilakukan Dewi Setyowati (2013) bahwa diperlukan peningkatan pengetahuan head nurse pada fungsi pengorganisasian dengan pembentukan struktur organisasi, uraian tugas, pelatihan budaya keselamatan pasien, pendidikan keperawatan berlanjut, diskusi keselamatan pasien, sistem penghargaan atas penerapan budaya keselamatan pasien (19).

\section{Sikap dengan Kinerja Perawat}

Individu akan bersikap terhadap suatu permasalahan yang dihadapi tergantung dari pengetahuan yang dimiliki. Sikap 
merupakan kumpulan komponenkomponen kognitif, afektif dan konatif yang saling berinteraksi dan memahami, merasakan, dan berperilaku terhadap suatu obyek (Azwar, 2010), dalam penelitian ini sikap perawat kategori baik dengan kinerja perawat baik sebesar $86,6 \%$, perawat dengan sikap kurang dengan kinerja kurang 68,1 artinya bahwa sikap perawat dalam penerapan sistem keselamatan pasien itu baik dan berpengaruh positif dalam peningkatan kinerja perawat (20).

Dalam kaitan hubungan antara sikap dengan kinerja ini, ada beberapa hasil penelitian yang cukup menarik untuk dicermati. Gibson (1997) menyebutkan bahwa sikap adalah determinan perilaku, sebab sikap berkaitan dengan persepsi, kepribadian dan motivasi (21). Sikap positif jelas sangat dipentingkan untuk mendukung penerapan SKP di rumah sakit. Unit kerja rumah sakit dengan frekuensi dan derajat keparahan (severitas) terjadinya IKP adalah Kamar Operasi. IPSG 4 berfokus pada keselamatan pasien di Kamar Operasi. Pada hasil variabel sikap ada 6 orang $(5,3 \%)$ yang menjawab STS dan 43 orang $(37,7 \%)$ yang menjawab TS terhadap pertanyaan negatif = Sangat tidak bermanfaat memperhatikan perhitungan semua bahan yang memasuki area steril selama prosedur pembedahan. Pernyataan ini merupakan upaya mencegah tertinggalnya benda asing selama prosedur pembedahan terutama untuk organ-organ berongga. Hal ini sesuai dengan hasil pada variabel kinerja, oleh penilaian atasan langsung dalam parameter akurasi. Ada 90 perawat $(78,9 \%)$ yang dinilai baik dan
7 Perawat $(6,1 \%)$ yang dinilai sangat baik oleh atasan langsung, pada Pernyataan Kemampuan menghitung seluruh bahan yang memasuki area steril dalam proses pembedahan. Kesesuaian ini dimungkinkan adanya hubungan antara sikap perawat dengan kinerjanya, walaupun tidak semua perawat berasal dari unit kamar operasi. Hal ini perlu mendapat perhatian karena tertinggalnya benda asing selama prosedur pembedahan merupakan indikator keselamatan pasien rumah sakit

Hubungan antara sikap responden dengan penilaian kinerja, juga tampak pada pelaporan IKP. Ada 44 perawat $(38,6 \%)$ STS dan 38 perawat $(33,3)$ TS pada pernyataan : Bila terjadi IKP selama pasien di rumah sakit tidak harus dilaporkan, dianalisis atau dikaji bersama sebab-sebabnya untuk untuk dijadikan bahan pembelajaran bersama. Hal ini sesuai dengan hasil pada variabel kinerja parameter administrasi, dimana ada 91 perawat $(79,8 \%)$ yang dinilai baik dan 1 perawat $(0,9 \%)$ yang dinilai sangat baik dalam : Kemampuan membuat laporan secara tertulis bila terjadi IKP.

Dalam hal sikap responden ini ada dua sikap yang juga perlu mendapat perhatian yaitu, pada sikap terhadap obat-obat konsentrasi pekat (IPSG 3) dan sikap terhadap adanya singkatansingkatan di rumah sakit yang membingungkan staf yang dianggap bukan penyebab terjadinya IKP (IPSG 2). 
Kualitas Kerja dan Kinerja Perawat

Penilaian kinerja perawat merupakan mengevaluasi kinerja perawat sesuai dengan standar praktik professional dan peraturan yang berlaku. Penilaian kinerja perawat merupakan suatu cara untuk menjamin tercapainya standar praktek keperawatan. Penilaian kinerja merupakan alat yang paling dapat dipercaya oleh manajer perawat dalam mengontrol sumber daya manusia dan produktivitas. Proses penilaian kinerja dapat digunakan secara efektif dalam mengarahkan perilaku pegawai, dalam rangka menghasilkan jasa keperawatan dalam kualitas dan volume yang tinggi. Perawat manajer dapat menggunakan proses operasional kinerja untuk mengatur arah kerja dalam memilih, melatih, membimbing perencanaan karier serta memberi penghargaan kepada perawat yang berkompeten (22).

Hasil uji statistic menjelaskan ada hubungan antara Kualitas Kerja dengan kinerja perawat di Rumah Sakit Umum Daerah Sinjai. Dalam analisis hubungan keterkaitan Kualitas Kerja dengan kinerja perawat dalam penerapan sistem keselamatan pasien di rumah sakit, dapat dilihat dari pernyataan : selalu dilibatkan dalam pembahasan kasus-kasus keperawatan, ada 80 perawat $(70,2 \%)$ menjawab sangat setuju yang singkron dengan penilaian kinerja perawat oleh atasan pada pernyataan kepatuhan melakukan pengkajian secara bersama-sama apabila terjadi kasus IKP, 74 perawat $(64,9 \%)$ dinilai baik dan pernyataan keaktifan dalam melakukan diskusi kasus IKP, 76 perawat $(66,7)$ dinilai baik oleh atasan secara langsung, pernyataan K.4 : ada jaminan rasa aman bekerja di unit kerja pelayanan di rumah sakit ini, 96 perawat $(84,2 \%)$ setuju dan pada pernyataan KP22 : kedisiplinan melaksanakan pemantauan penerapan SPO keperawatan di unit kerjanya, 80 perawat $(70,2)$ dinilai baik.

Menurut saleh, dkk (2020) ketika karywan terlindungi secara psikologis dapat meningkatkan kupuasan kerja, sikap yang baik dan peningkatan kinerja karyawan dan ketika karyawan tidak aman secara psikologis dapat mengalami demoralisasi, ancaman, pelepasan dan ketegangan. Rasa aman yang dimaksud adalah keamanan fisik, karena karyawan yang bekerja dilingkungan yang dianggap aman secara fisik akan merasa lebih aman Selanjutnya, pegawai yang memiliki rasa keterlibatan dalam organisasi merasa terhubung dengan pekerjaan mereka karena dapat berhubungan dan berkomitmen pada keberhasilan dan misi organisasi mereka, keterlibatan penting untuk kepuasan individu dan kesehatan psikologis karena mengarah pada peningkatan profitabilitas bagi organisasi, kepuasan pelanggan, peningkatan kinerja, moral, motivasi kerja dan peningkatan perilaku yang menguntungkan organisasi (23).

Organisasi yang tidak menerapkan keterlibatkan karyawan akhirnya berdampak pada penurunan produktivitas, psikologis dan penurunan kinerja karyawan. Penelitian ini sama dengan penelitian Usman, (2009) yang mendapatkan hasil ada pengaruh Kualitas Kerja terhadap 
semangat kerja pada pekerja Pertamina Eksplorasi dan Produksi Rantau. Namun hanya tiga komponen Kualitas Kerja yang diteliti yaitu restrukturisasi kerja, sistem imbalan dan lingkungan kerja (24).

Ketiga komponen tersebut secara bersama-sama berpengaruh secara signifikan terhadap semangat kerja, tetapi secara terpisah hanya variabel restrukturisasi kerja yang berpengaruh terhadap semangat kerja, sedangkan sistem imbalan dan lingkungan kerja tidak signifikan berpengaruh terhadap semangat kerja. Walaupun komponen Kualitas Kerja dan variabel diteliti yang berbeda, hal ini menunjukkan adanya salah satu komponen Kualitas Kerja mempunyai korelasi secara signifikan terhadap kinerja. Berkaitan dengan teori-teori penting dalam Penerapan sistem keselamatan pasien, Kualitas Kerja rumah sakit dapat merupakan ujung tumpul atau latent error kontribusi terjadinya IKP.

\section{KESIMPULAN}

Berdasarkan data-data
penelitian yang telah dibahas
dapat diambil kesimpulan bahwa
terdapat hubungan antara pengetahuan,
sikap, kualitas kerja terhadap kinerja
perawat dalam penerapan sistem
keselamatan kerja di Rumah Sakit
Umum Daerah Sinjai.

\section{Saran}

Beberapa saran penulis dapat berikan yakni 1) Mengembangkan program peningkatan pengetahuan tentang sistem keselamatan pasien. 2)
Melaksanakan evaluasi dalam bentuk audit mutu pelayanan keperawatan terhadap penerapan standar keselamatan pasien. 3) Mengembangkan standar kinerja perawat yang mendukung penerapan konsep keselamatan pasien dalam indikator mutu pelayanan keperawatan. 4) Masih ada perawat yang bersikap kurang mendukung untuk implementasi materi IPSG 4 di kamar operasi. Hal ini memerlukan komitmen yang kuat dari pihak manajemen rumah sakit umum daerah sinjai untuk membangun dan memperbaiki sikap perawat tersebut melalui kegiatan pelatihan, pendidikan dan sosialisasi yang berkesinambungan.5) Perlu ditingkatkan upaya memperbaiki kualitas kerja rumah sakit dan komponennya terutama upaya penyelesaian masalah dengan tidak menyalahkan dan menghukum serta penyediaan alat yang lengkap untuk perlindungan terkena penularan penyakit infeksius di unit kerja rumah sakit.

\section{DAFTAR PUSTAKA}

1. Departemen Kesehatan RI. (2015). Indikator Kinerja Rumah Sakit, Direktorat Jendral Pelayanan Medik.

2. Saleh, L. M., Russeng, S. S., \& Tadjuddin, I. (2020). Manajemen Stress Kerja (Sebuah Kajian K3 dari Aspek Psikologis Pada ATC). Yogyakarta: Deepublish

3. Komite Keselamatan Pasien Rumah Sakit. (KKP-RS),(2015). Pedoman Pelaporan Insiden Keselamatan Pasien (IKP).

4. Departemen Kesehatan RI. (2015). Buku Pedoman Upaya Peningkatan 
Mutu Pelayanan Rumah Sakit (Konsep dasar dan Prinsip), Direktorat Jendral Pelayanan Medik , Direktorat Rumah Sakit Khusus dan Swasta.

5. Wahyuddin, Purwanto (2006). Pengaruh Faktor-Faktor Kepuasan Kerja Terhadap Kinerja Karyawan Pusat Pendidikan KomputerAkuntansi IMKA di Surakarta. Program Pascasarjana. Surakarta: Universitas Muhammadiyah Surakarta.

6. Gunibala, T. (2015) Hubungan Pengetahuan dan Sikap Perawat dengan Penerapan Patient Safety di RSUD Prof. Dr. H. Aloei Saboe Kota Gorontalo. Skripsi. Jurusan Ilmu Keperawatan, Fakultas Ilmu-Ilmu Kesehatan dan Keolahragaan, Universitas Negeri Gorontalo.

7. Notoatmodjo, S. (2010). Manajemen Sumber Daya Manusia. Jakarta : Rajawali Pers

8. Azwar, (2013). Teori Sikap. Yogyakarta : Pustaka Belajar

9. Mahardikawanto (2013). Pengaruh Disiplin Kerja, Lingkungan Kerja, Dan Kualitas Kehidupan Kerja Terhadap Kinerja Karyawan Rsud Dr. M. Ashari Pemalang. Skripsi. Semarang: Fakultas Ekonomi, Universitas Negeri Semarang

10. Arifin, Noor. (2012). Analisis Kualitas Kehidupan Kerja, Kinerja, dan Kepuasan Kerja Pada CV. Duta Senenan Jepara. Journal Economia, Vol. 8 No. 1. Hal 11-21. Jepara: Stienu Jepara

11. Penerapan Sistem Keselamatan Pasien di Rumah Sakit di Indonesia

12. RSUD Sinjai. Profil RSUD Kabupaten Sinjai 2018. Diakses pada https://rsudsinjai.com/\# (11 Januari 2020)

13. Sugiyono (2018). Metode Penelitian Kuantitatif, Kualitatif, dan $R \& D$. Bandung : Alfabeta.

14. Notoatmodjo, S. (2007). Filsafat Ilmu Edisi I. Jakarta : Rajawali Pers

15. Mangkuprawira (2008) Mangkuprawira, 2014, Manajemen Sumber Daya Manusia Strategik, Indonesia, Jakarta : Ghalia.

16. Yulia, Sri. (2010) Pengaruh Pelatihan Keselamatan Pasien Terhadap Pemahaman Perawat Pelaksana Mengenai Penerapan Keselamatan Pasien di RS Tugu Ibu. Tesis Fakultas Ilmu Keperawatan UI. Depok.

17. Idayanti (2008). Hubungan Pengetahuan dan Sikap Perawat terhadap penerapan Standar Operasional Prosedur (SOP) Teknik menyuntik dalam Upaya pencegahan infeksi di RSUD Arifin Achmad Pekanbaru.

18. Notoatmodjo S. (2010). Ilmu Perilaku Kesehatan. Jakarta: PT Rineka Cipta.

19. Setiowati, Dwi (2013). Kepemimpinan Efectif Head Nurse Meningkatkan Penerapan Budaya Keselamatan Pasien oleh Perawat Pelaksana RSUPN Dr. Cipto Mangunkusumo Jakarta. Tesis Fakultas Ilmu Keperawatan - UI : Depok.

20. Azwar, (2013). Teori Sikap. Yogyakarta : Pustaka Belajar

21. Gibson JL., Ivancevich JM , Donnelly JH. (2014). Organisasi: Perilaku, Struktur, Proses. Alih bahasa: Ir. Nunuk Adiarni, MM., 
Dr. Lyndon Saputra, Binarupa Aksara, Publisher.

22. Nursalam. (2011). Proses dan Dokumentasi Keperawatan Konsep dan Praktik. Jakarta: Salemba Medika

23. Saleh, 1. m., russeng, s. s., \& tadjuddin, i. (2020). Manajemen Stres Kerja. Yogyakarta: Cv Budi Utama

24. Usman E.J (2009). Pengaruh Quality Of Work Life terhadap Semangat Kerja di Pertamina Eksplorasi dan Produksi Rantau. Tesis Tugas Akhir Program Magister (TAPM) Program Pasca Sarjana Universitas Terbuka, Jakarta. 